\title{
ANALISIS KONDISI PEMUKIMAN PENDUDUK DALAM PERTUMBUHAN EKONOMI INDONESIA
}

\author{
TEGUH SANTOSA ${ }^{1}$, RINOVIAN RAIS ${ }^{2}$ \\ $\underline{\text { teguh@ibm.ac.id }}{ }^{1}, \underline{\text { rinovianrais@ibm.ac.id }}{ }^{2}$ \\ Program Studi Ekonomi Pembangunan', Program Studi Manajemen² \\ Institut Bisnis Muhammadiyah Bekasi
}

\begin{abstract}
ABSTRAK
Hampir disemua Negara banyak dibahas tentang pemukiman penduduk sekaligus dalam penelitian ini peneliti menggunakan hasil dari bahan-bahan kajian yang dibahas tentang pemukiman yang ada pada negara lain dengan termasuk negara indonesia, ada dua peneliti menemukan beberapa yaitu bentuk konsumsi serta tata letak perkotaan dan sekitar manusia seperti lingkungan, dimana juga keadaan keilmuan sudah cocok pada kualitas tempat tinggalyang ada. Terdapat juga beberapa kualitas kekuatan manusia yang terbatas dan banyak jenis perumahan yang ada di indonesia dalam bentuk interaksi masyarakatnya dalam sektor publik.
\end{abstract}

Kata Kunci: Pemukiman Penduduk, Pertumbuhan Ekonomi

\section{ABSTRACT}

In almost all countries there is a lot of discussion about population settlements as well as in this study researchers used the results of study materials discussed about settlements in other countries with those in indonesia, there were two research findings, namely the process by which people purchase and consume products and services to satisfy their needs, urban also neighborhood arrangement, which also scientific conditions are in accordance also condition of including indonesia state, there are also some qualities of limited human strenght and many types of housing available in Indonesia's infrastructure from the interaction of the commmunity in the public sector.

Key Words: population settlement, economic growth.

\section{PENDAHULUAN}

\section{Latar Belakang Masalah}

Dinamika kependudukan dalam permintaan perumahan pemukiman penduduk Malimping utara, Kecamatan Malimping, Kabupaten Lebak, serta rumah tangga baik untuk pertumbuhan, penyebaran, perkembangan rumah tangga dan juga mobilitas penduduk. Ada beberapa aspek pemukiman penduduk yang menjadi masalah dan juga sebagai dinamika penduduk yang perlu dicatat terkait 
antara perumahan dengan kependudukan.

Pertama, laju pertumbuhan penduduk nasional serta perkembangan penduduk yang ada di perkotaan tidak merata. Kedua, laju pertumbuhan penduduk lebih rendah bila dibandngkan laju pertumbuhan rumah tangga yang menyebabkan adanya jumlah penduduk per rumah tangga makin kecil. Perumahan atau pemukiman bisa dijadikan instrumen dalam meihat pencapaian akan sasaran pembangunan, baik yang ada di daerah maupun di perkotaan, yang menjadi tujuan dalam pembangunan yang ada di Indonesia.

Bagian yang tidak lepas dari kajian dalam mengatasi masalah kependudukan dalam mengkaji pemukiman itu sendiri. Yang juga merupakan utama dalam suatu masalah baik masyarakat yang ada disuatu desa atau kota.

Kelangsungan hidup penduduk juga membutuhkan untuk berlindung dari panas dan hujan atau rumah layak huni yang terdapat pada pemukiman atau cluster pemukiman. Yunus (2007) menurutnya teradapat beberapa bentuk peta geografi pemukiman dikatagorikan menjadi dua yaitu pemukiman pedesaan (Settlement in villages) dan pemukiman perkotaan (Settlement in cities).

Bila sewaktu-waktu terjadi lonjakan penduduk lahir akan terjadi kebutuhan akan perumahaan untuk tempat tinggal atau tanah pemukiman, mempunyai dampak semakin tingginya harga beli lahan atau tanah tersebut.

Sedangkan Yudohusodo (1991) mempunyai pendapat dimana pemukiman masyarakat ekonomi yang dikarenakan kalau masyarakat memiliki lahan yang diartikan sebagai investasi jangka panjang serta dapat menjamin kehidupan dimasa yang akan datang. Dimana keadaan pemukiman tentunya juga banyak memiliki perbedaan.

Pertumbuhan penduduk serta banyaknya pendatang dari daerah lain di Desa Malimping utara, Kecamatan Malimping, Kabupaten Lebak mengakibatkan tingginya tingkat pembangunan pemukiman pada lahan sempit yang berpenduduk padat.

Pemukiman di Desa Malimping utara, Kecamatan Malimping, Kabupaten Lebak yang sering dipermasalahkan diantara peningkatan masyarakat dengan jumlah lahan yang tersedia.Banyaknya masyarakat yang juga membutuhkan perumahan bagi penduduk apakah perumahan bagi orang-orang indonesia serta untuk orang-orang luar pemukiman tersebut.

\section{Tujuan Penelitian:}

Adapun tujuan dari penelitian ini adalah:

1. Bentuk-bentuk perumahan malimpin utara kecamatan malimping kabupaten lebak sudah sesuai dengan struktur tanah baik bentuk sosial ekonominya atau dari tempat pekerjaannya. 
2. Kualitas perumahan pemukiman di malimping utara kecamatan malimping kabupaten lebak untuk mengetahui adanya hubungan sosial ekonomi yang ada di pedesaan atau sebaliknya.

\section{TINJAUAN PUSTAKA}

Finch (1957) yang ada pada Ritohardoyo (2000) yang menyatakan bahwa tempat tinggal kediaman masyarakat juga mempunyai kelompok-kelompok kesatuan atau organisasi apakah lingkungan perumahan mempunyai fasilitas umum dan fasilitas khusus seperti sarana prasaranalingkungan sehingga akan mendapat pelayanan yang baik serta mempunyai udara yang segar tidak terjadi polusi udara, serta jalan dan penerangan jalan.

Hadi S. Yunus (1987) dalam Wesnawa (2015:2) mengartikan buatan manusia ataupun yang asli untuk melengkapi dalam kehidupan manusia yang mandiri atau yang berkelompok dalam suatu perumahan untuk menetap mencari penghidupan.

Perumahan (housing) cluster temapat untuk berteduh dalam suatu area komplek perumahaan tempat tinggal yang juga mempunyai lingkungan yang asri tamannya sekaligus dilengkapi adanya sarana dan prasarana dalam lingkungan perumahan (sadana 2014:190.

Kuswartojo (2005) mengartikan perumahan penduduk dalam suatu lingkungan perkotaan yang ada di Indonesia tinggi jumlah penduduknya daripada di pedasaan. Pertumbuhan penduduk di kota besar yang mengakibatkan penduduk perkotaan menjadi penuh sehingga kegiatan ekonominyapun tinggi.

Pengertian perumahan menurut Budiharjo (1998:148) mengatakan bahwa manusia yang mempunyai tempat tinggal untuk dapat meneduh dari panasnya matahari disiang hari dan udara dingin dimalam hari. Dimana sebagai wadah kehidupan baik menyangkut beberapa aspek teknis serta fisik yang diikuti dengan aspek sosial, ekonomi dan budaya masingmasing masyarakat yang ada dilingkungan perumahan.Perbedaan diantara pemukiman dan perumahan yang terletak fungsinya, kawasan pemukiman memiliki lingkungan pada fungsi ganda yaitusebagai tempat tinggal dan tempat mencari nafkah (Sadana 2014:20)

Wesnasa mengutip pendapat Lewis Mumford dalam bukunya (2015:27), yakni bahwa ada enam tahapan perkembangan terkait pemukiman penduduk kota, yaitu:

1. Tahap awal, yaitu perkembangan desa. Dalam hal ini masyarakatnya sudah teratur, sehingga mengalami perkembangan, yakni dari kehidupan desa beralih menuju bentuk kehidupan di kota.

2. Dimana suatu daerah yang penduduknya bersifat sebagai daerah agraris ini yang disebut tahap polis. 
3. Masyarakat yang penduduknya mempunyai kehidupan ekonomi menuju pada sektor industri ini yang disebut tahap metropolis.

4. Dimana suatu daerah dalam suatu perkotaan terdiri ada beberapa adanya kota metropolis yang membentuk pada jalur-jalur untuk menuju perkotaan yang disebut dengan tahap megapolis.

5. Kota yang ditandai adanya kekacauan dalam pelayanan umum, juga didaerah tersebut terjadi kemacetan disertai terjadinya tingkat kriminal yang tinggi ini yang disebut dengan tahap tryanopolis.

6. Kota dimana penduduk sudah banyak meninggalkannya sehingga kota tersebut tidak ada aktifitas warganya yang sebut dengan tahap necropolis.

Ada dua tipe pemukiman menurut Wesnasa (2015:32) yaitu:

1. Tipe pemukiman didasarkan pada sudah berapa lama hunian ditinggalkan atau ditempati ini dibedakan apakah ditemapatinya dalam bentuk sementara atau permanen, rumah yang dihuni bersifat sementara dapat dihitung dengan beberapa hari (biasanya pengembara), huunian yang ditempati hanya beberapa bulan (pekerja musiman atau biasa disebut juga rumah kosan atau kontrakan bulanan), sedangkan hunian untuk beberapa tahun biasanya orang yang bekerja di luar untuk beberapa tahun saja. Untuk tipe pemukiman permanen yang dibangun untuk waktu yang tidak terbatas sehingga yang menempatinya menjadi aman dan nyaman.

2. Tipe pemukiman didasarkan pada fisik dan non fisik, pada dasarnya pemukiman memiliki kelenturan dalam struktur ketika mengalami perubahan. Ini terjadi pada pemukiman yang cukup besar. Saat mengalami perubahan, mengalami juga pertumbuhan. Ketika sebuah pemukiman menjadi kian besar, pada saat itu pula terjadi perubahan pada rencana, ukuran, bentuk, gaya bangunan, sifat, serta fungsi dan kepentingan. Pada dasarnya, semua dipertimbangkan yang dipakai adalah dalam untuk membangun jati dari masingmasing. Di mana di dalamnya mencakup: ciri khas, baik dalam fisik, sejarah, arsitektur, peranan fungsi, serta keunikan masing-masing.

Pertumbuhan penduduk Malimping Utara Kecamatan Malimping Kabupaten Lebak dalam perkembangan serta aktivitas yang diikuti dalam sarana dan prasarana perkotaan yang mempunyai fasilitasnya. Penurunan kualitas lingkungan perkotaan mempunyai lima faktor yaitu: pencemaran karena teknologi, mewahnya untuk konsumsi serta limbah yang dihasilkan yang disebabkan oleh kerawanan sosial, kemiskinan, pengambilan keputusan yang tepat 
serta cepatnya pertumbuhan penduduk.

Pertumbuhan penduduk merupakan salah satu akibatnya, tapi bila dilihat secara mendalam faktor yang dominan merupakan faktor penduduk serta rumah tangga yang menyebabkan ketidakseimbangan berupa lingkungannya (Shaw:1991).

Esensi dari keberadaan perumahan serta pemukiman bagi pengembangan di daerah perkotaan ialah karena faktor keberadaan rumah menjadi salah satu penyebab terjadinya ketidakseimbangan lingkungan pemukiman. Kepadatan penduduk yang melebihi daya tampung.

Penduduk Malimping Utara, Kecamatan Malimping, Kabupaten Lebak merupakan salah satu yang mendapat perhatian serius dalam pertumbuhan kota-kota. Menurut Bintaro (1977) Perkembangan penduduk desa yang berada di sekitar wilayah perkotaan merupakan salah satu faktor yang mempengaruhi perubahan kemajuan desa itu sendiri sehingga nantinya akan berubah menjadi perkotaan.

Perubahan dari desa menjadi kota juga dipengaruhi oleh karakteristik penduduk desa itu sendiri, tak terkecuali kawasan pemukiman di Malimping Utara Kecamatan Malimping Kabupaten Lebak. Adanya urbanisasi turut pula menjadi faktor yang menyebabkan perubahan. Sehingga kota-kota akan berkembang menjadi kota metropolis.
Akibat yang langsung terlihat dengan adanya urbanisasi tersebut adalah tersedianya tenaga-tenaga kerja yang murah di kota-kota. Sebab jumlah penduduk di kawasan perkotaan yang menjadi membludak jumlahnya dan semuanya butuh penghidupan. Dengan demikian, jelaslah bahwa urbanisasi sangat besar pengaruhnya terhadap pertumbuhan dan perkembangan penduduk di sebuah wilayah.

Selain bisa menjadi faktor yang menyebabkan munculnya masalahmasalah bagi perkotaan, urbanisasi juga menybabkan munculnya beberapa keuntungan yaitu dalam hal penyediaan tenaga kerja. Dengan adanya urbanisasi tersebut, tenaga kerja di kawasan kota menjadi beragam dan mudah didapatkan. Pada umumnya, di kota-kota besar selalu terjadi aglomerasi kependudukan di berbagai bidang. Hal tersebut terlihat dari pesatnya perubahan dan perkembangan pada aktivitas politik, ekonomi, serta kebudayaan. Pusat-pusat kegiatan untuk itu semua pun secara otomatis bermunculan, seperti: munculnya perkantoran, pusat perdagangan, universitas, dan lain sebagainya, sehingga industri tumbuh dan berkembang dengan pesat.

Gejala sosial yang muncul di kawasan tersebut adalah timbulnya persaingan dalam upaya memperebutkan lokasi yang ada di sekitar pusat-pusat kegiatan tersebut. Jadi, bisa dikatakan, gejala sosial yang terjadi bukan hanya perihal peningkatan jumlah penduduk yang tinggi sehingga 
tidak sebanding dengan luas tanah yang ada, tetapi juga dalam hal persaingan yang semakin tinggi pula dalam mendapatkan tempat untuk hidup, selain bersaing untuk mendapatkan tanah untuk lokasi usaha dan kepentingan yang mendukung usaha. Misalnya: tanah untuk perkantoran, tempat industri, jalan umum, taman, dan lain sebagainya. Hal ini sesuai dengan apa yan dikemukakan oleh Nasution (1992) yakni bahwa persaingan mendapatkan tanah yang terbatas luasnya cenderung terjadi pada lokasi yang dekat dengan pusatpusat kegiatan kota. Hal itu terjadi di Malimping Utara sebab pertambahan penduduknya yang pesat.

Makna kualitas pemukiman sangat berbeda-beda, sesuai dengan usaha yang dimiliki oleh penghuni pemukiman tersebut. Kualitas sebuah pemukiman juga termasuk mencakup di dalamnya perihal: kondisi rumah; kondisi lingkungan, dalam hal ini adalah warga sekitar yang mendiami pemukiman tersebut; kualitas bangunan rumah; fasilitas yang dimiliki, baik fasilitas khusus maupun fasilitas umum yang sangat dipengaruhi oleh biofisik.

Letak kondisi Malimping Utara, Kecamatan Malimping, Kabupaten Lebak terdiri dari biofisik yang meliputi topografi, bebatuan, tanah, dan air serta vegetasi. Juga komponen manusia yang secara individu sangat memiliki pengaruh. Kualitas pemukiman sangat dipengaruhi oleh faktor pendapatan, pekerjaan, dan juga pendidikan.
Kualitas pemukiman juga terlihat dari kondisi lingkungan dari penghuninya. Semakin baik orangorang yang menghuninya, maka semakin baik pula kondisi pemukiman tersebut.

Sementara itu, yang berkaitan dengan perihal sosial ekonomi ialah hal-hal tentang pemenuhan kebutuhan hidup, seperti: sandang, pangan, papan, pemukiman, pendidikan, kesehatan. Menurut Melly G Tan, kebutuhan hidup erat kaitannya dengan pendapatan seseorang di dalam lingkungan pemukiman.

Koentjaraningrat dalam bukunya mengatakan bahwa, kedudukan sosial serta ekonomi seseorang bisa dilihat dari aspek pendapatan, pekerjaan, serta pendidikan. Dengan berdasarkan itu pula masyarakat diklasifikasikan ke dalam penggolongan ekonomi rendah, ekonomi sedang, serta ekonomi tinggi. Faktor ekonomi dan sosial menjadi penentu baik atau buruknya kualitas pemukiman di sebuah wilayah.

Peningkatan jumlah penduduk membuat kebutuhan akan tanah menjadi semakin tinggi. Baik itu untuk keperluan pemukiman ataupun untuk keperluan fasilitas umum, sementara ketersediaan tanah semakin hari semakin terbatas. Karenanya kebijakan perihal tanah terdorong untuk dibuat oleh pihak yang berwenang, dalam hal ini pemerintah. Dengan adanya kebijakan-kebijakan tersebut membuat pemerintah menjadi fasilitator serta mediator 
bagi kedua belah pihak, yakni bagi pihak konsumen, dalam hal ini masyarakat/ penduduk dengan pihak pengembang (developer), bahkan juga dengan lembaga keuangan yang terkait dengan proyek pembangunan pemukiman.

Pembangunan pemukinan di wilayah Malimping Utara, Kecamatan Malimping, Kabupaten Lebak dengan sendirinya membuat terjadinya pertumbuhan penduduk di wilayah itu. Sebab, dengan bertambahnya penduduk kebutuhan akan tanah untuk pemukiman dengan sendirinya juga mengalami peningkatan. Hal itu sejalan dengan pendapat yang dikeluarkan oleh Suyanto (1997), bahwa tanah adalah aset bagi pemukiman perkotaan yang terbatas, sedangkan kebutuhan masyarakat tidak terbatas. Sehingga pada perkembangannya menjadikan tanah sebagai komoditi ekonomi yang bernilai mahal.

Asas manfaat dalam pengelolaan pertanahan sangat diharapkan mengandung asas adil serta merata dengan semangat kekeluargaan, kesetiakawanan, kebersamaan, keakraban, keterjangkauan, juga kelestarian lingkungan hidup. Semangat-semangat tersebut dikembangkan dalam rangka upaya membina ebabling atau kemampuan, accessibility and affordability atau penciptaan iklim yang memudahkan dan keterjangkauan, role sharing atau berbagi peran, alam pemukiman berkelanjutan, dan sustainable and justifiable atau berkeadilan. Harsono (1993) mengemukakan saran perihal kemitraan. Di mana hal itu dalam pembangunan pemukiman sangat diperlukan. Sebab tanah untuk membangun properti sudah diatur oleh pemerintah.

Provinsi Banten bekerjasama dengan developer perumahan Malimping Utara Kecamatan Malimping Kabupaten Lebak dalam penataan dan pengelolaan yang siap dibangun (Lisiba). Pembentukan bank tanah yang ditindaklanjuti pada penertiban perijinan pembangunan perumahan dan hak tanah yang sudah ditelantarkan juga dilaksanakan. Semakin komplek masalah pembangunan perumahan serta pemukiman, maka dibentuklah sebuah wadah yang bernama forum komunikasi perumahan serta pemukiman mulai dari tingkat daerah hingga pusat. Anggotanya terdiri dari unsur pemerintah, pengembang (swasta), masyarakat, dan juga para ahli yang dalam hal ini adalah pakar perumahan. Dalam dorum tersebut dibahas tentang problem-problem tentang perumahan beserta pemecahannya.

Di kawasan pemukiman perumahan Malimping Utara Kecamatan Malimping Kabupaten Lebak, antara lahan siap bangun dengan kapling tanah matang, serta pengadaan pemukiman lainnya saling dukung satu sama lain, yakni dalam pelaksanaan pengelolaan lahan beserta SDM serta perihal ruang kelola, konsilidasi tanah.

Perumahan serta pemukiman malimping utara kecamatan malimping kabupaten Lebak juga perlu ikut serta dalam usaha nirlaba 
dan lembaga swadaya masyarakat yang berkaitan dengan pemukiman, yayasan, koperasi, developer, mediator. Perumahan pemukiman harus ditingkatkan agar dapat dicapai efisiensi serta effektifitas pembangunan yang sudah terencana tersusun secara terpadu berkelanjutan sangat penting dengan adanya kebijakan tata ruang wilayah daerah atau perkotaan.

\section{METODOLOGI PENELITIAN}

Analisis pustaka hanya bermakna untuk membaca literatur yang akhirnya akan mengevaluasi secara mendalam serta kritis suatu penelitian nya bersifat kualitatif deskriftif dengan menjelaskan semua sumber yang didapat pada sumber primer dan obyektif yang mendalam pengevaluasian penelitian (Shuttleworth, 2009) semua data sekunder terkait pemukiman.Data dari beberapa provinsi Banten secara bersamasama dengan kabupaten Lebak yang berkaitan dengan perumahan pemukiman dimana peneliti juga menganalisis perkembangan perumahan selama tiga tahun terakhir ini.

Teori-teori tentang perkembangan perumahan pemukiman malimping utara kecamatan malimping kabupaten Lebak juga dikaitkan dengan kondisi masyarakat serta tinjauan dari literatur pustaka untuk menjadi bahan kajian yang hendak dianalisis dengan temuan empiris dari beberapa penelitian relevan sebelumnya.
Kecamatan malimping kabupaten Lebak secara administratif juga terletak di provinsi Banten pantai selatan pulau jawa diharapkan akan menjadi daerah dengan kondisi fisik pemukiman yang cenderung homogen, namun sering adanya beberapa perubahan aktifitas ekonomi masyarakat desa sehingga fasilitas sarana dan prasarana serta aksenya akan bertambah maju.

Data terkumpul setelah itu dianalis serta dilakukan secara deskriftif kaulitatif yang menjabarkan semua data-data yang ada untuk menentukan klasifikasi kondisi fisik pemukiman sosial ekonomi dan mengetahui hubungan antara faktor sosial ekonomi terhadap kualitas pemukiman Malimping Utara Kecamatan Malimping Kabupaten Lebak,

Kabupaten lebak merupakan salah satu kabupaten di Provinsi Banten. Terdiri dari 28 kecamatan, 340 desa, serta 5 kelurahan. Luas wilayahnya mencapai 304.472 ha. Berdasarka data dari BPS Kabupaten Lebak, jumlah penduduknya sebanyak 1.204 .095 jiwa.

Faktor-faktor Indikator pemukiman menurut BPS yaitu:

1. Kepemilikan rumah sendiri mempunyai status rumah tangga dalam persentase.

2. Kepemilikan rumah sewa atau kontrak, mempunyai status rumah tangga dalam persentase.

3. Sebagian besar atapnya bukan ijuk/lainnya menurut rumah tangga dalam persentase. 
4. Sebagian besar dindingnya bukan bambu/lainnya, mempunyai status rumah tangga dalam persentase.

5. Lantai terluas bukan tanah mempunyai status rumah tangga dalam persentase.

6. Sumber air minum layak mempunyai status rumah tangga dalam persentase.

7. Sanitasi layak mempunyai status rumah tangga persentase.

8. Penerangan dan listrik PLN mempunyai status rumah tangga dalam persentase.

9. Luas hunian perkapita $<=7,7 \mathrm{~m}$ mempunyai status rumah tangga dalam persentase.

Kepemilikan hunian maka perumahan pemukiman ada dua katagori yaitu:

1. Hak milik perumahan pemukiman.

2. Hak sewa perumahan pemukiman.

Kepemilikan perumahan dalam hak milik dengan cara dicicil dimana perumahan pemukiman sudah bersertifikat hak milik atas nama perseorangan, dalam arti menggunakan nama pribadi.

Kepemilikan perumahan dalam status hak sewa adalah status rumah bukan milik dari orang yang menempati. Sehingga sewaktuwaktu pemilik rumah bisa mengambil alih rumahnya tersebut. Perumahan dalam bentuk sewa seperti ini banyak jumlahnya dan sering di temukan di mana-mana, termasuk di Malimping Utara Kecamatan Malimping, Kabupaten Lebak.
Tahun 2018-2019 menunjukan fakta menarik mayoritas penduduk malimping utara kecamatan malimping Kabupaten Lebak dimana mayoritas penduduk malimping utara mempunyai rumah sendiri dan rumah sewa.

Perumahan pemukiman malimping utara dalam status kepemilikan sewa ada yang seperti tersebut. Daerah tersebut industri dimana banyak tenaga kerja serta pendapatan masyarakat malimping utara kecamatan malimping kabupaten Lebak di analisis dibeberapa peneliti secara empiris.

Kabupaten Lebak mempunyai sosialisasi peningkatan kualitas rumah tidak layak huni dimana tahun 2018 terdapat 575 rumah dikabupaten lebak yang mendapat bantuan rumah tidak layak huni dari provinsi banten juga melalui peraturan pemukiman Provinsi Banten di kecamatan malimping, bayah, wanasalam, banjarsari semua wilayah tersebut kurang lebih 386 unit rumah tidak layak huni yang juga mendapat bantuan serta khususnya buat provinsi Banten dengan peningkatan perumahan pemukiman di malimping utara kecamatan malimping kecamatan malimping Kabuapten Lebak.

Pada tahun 2019 pemerintah daerah Kabupaten Lebak hanya bisa membantu sebagian rumah tidak layak huni dikarenakan keterbatasan pendapatan anggaran daerah (PAD) Kabupaten Lebak. Oleh karena itu Kabupaten Lebak meminta bantuan kepada Provinsi Banten untuk 
menangani rumah yang tidak layak huni di wilayahnya.

Program peningkatan kualitas rumah yang tidak layak huni menangani rumah-rumah dengan kategori tertentu, yakni yang hanya berupa bangunan rumah dengan luas bangunan rata-rata $36 \mathrm{~m} 2$, desain rumah dua kamar tidur, satu kamar mandi, satu ruang tamu dengan bahan-bahan bangunan serta listrik standar nasional indonesia (SNI). Program tersebut di kabupaten Lebak mempunyai harapan dalam pembangunan rumah tidak layak huni yang dianggarkan pada tahun berikutnya dimana mempunyai visi pemerintah Banten yang maju, mandiri, berdaya saing, sejahtera serta berakhlaqul karimah.

\section{PEMBAHASAN}

Beberapa peneliti sebelumnya menemukan temuan empiric yang berbeda-beda perihal kondisi perumahan penduduk di Malimping Utara, Kecamatan Malimping, Kabupaten Lebak-Banten ini. Masing-masing wilayah mempunyai aspek yang unik dan spesifik, yang mampu memberikan pengaruh terhadap pertumbuhan perumahan penduduk di Malimping Utara, Kecamatan Malimping, Kabupaten Lebak.

Perencanaan kota menitik beratkan pada ekonomi pasar bebas yang sangat berpengaruh terhadap pendapatan masyarakat. Bagi penduduk yang memiliki penghasilan kecil/ rendah akan mengalami kekurangan perumahan (Yap, K.S: 2016). Chia W. M. Li.
M \& tang, Y (2017) berpendapat, sektor publik swasta memiliki kontribusi fundamental ekonomi. Mencakup di dalamnya perihal: kendala keuangan, demografi, serta pasokan lahan. Baik pertumbuhan harga perumahan maupun swasta. Dari temuan penelitian tersebut menjelaskan, bahwa kesenjangan ekonomi yang mempengaruhi permintaan akan perumahan.

Kesenjangan tersebut berupa berkurangnya SDM terampil. Menurut Aquino, D.H (2018), terbatasnya cakupan tipe perumahan adalah tantangan bagi pengembangan rumah kokoh sesuai dengan wilayah perumaham pemukiman berkualitas.

Menurut A. A., Casni, A. C., \& Vizek, M. (2014), konsumsi pribadi, baik jangka pendek maupun jangka panjang memiliki dampak terhadap kesanggupan penduduk untuk memiliki rumah tinggal. Konsumsi jangka panjang yang relatif besar akan mengurangi pendapatan, sehingga berimbas pada menurunnya kemampuan untuk memiliki tempat tinggal.

Jumlah penduduk di Kabupaten Lebak mempunyai damapak pada penelitian empiris. Berdasar data yang ada, perencanaan dan penataan pembangunan yang dilakukan oleh pemerintah di daerah Malimping Utara, Kecamatan Malimping, Kabupaten Lebak belum maksimal.

Tata kota di Malimping Utara, Kecamatan Malimping, Kabupaten Lebak sudah sesuai dengan aturan, 
dalam menata kawasan industri. Akan tetapi, masih kurang maksimal dalam pengelolaan serapan air, saluran air dan irigasinya. Selanjutnya ekonomi pasar bebas khususnya di Malimping Utara Kecamatan Malimping Kabupaten Lebak sangat mempengaruhi kondisi perekonomian penduduk yang mayoritas adalah petani dan nelayan. Tingkat pendapatan masyarakat bisa dilihat dari nilai PDB atau produk domestik bruto selama tiga tahun belakangan. Oleh karena pasar bebas memberikan dampak pada perekonomian masyarakat Malimping Utara Kecamatan Malimping, Kabupate Lebak, maka dampaknya terhadap pertumbuhan perumahan penduduk di daerah itu pun terlihat.

Adanya program pengembangan perumahan penduduk yang dikelola swasta sangat bisa dirasakan oleh masyarakat Malimping Utara, yakni dengan ketersediaannya perumahan dengan harga yang terjangkau bagi masyarakat. Ukuran rumah serta fasilitas yang mendukung, menjadi daya pikat tersendiri bagi penduduk Malimping Utara. Fasilitas-fasilitas itu misalnya: Akses jalan raya yang mendukung, fasilitas pendidikan, fasilitas kesehatan, sarana irigasi, dan lain sebagainya.

Pola konsumsi khususnya masyarakat perumahan pemukiman malimping utara kecamatan malimping kabupaten Lebak dalam mengelola pendapatan sendiri yang ada di malimping sehingga tingkat konsumsi masyarakatnya juga akan membantu untuk program perumahan pemukiman, apakah dengan program rumah tidak layak huninya.

\section{KESIMPULAN DAN SARAN}

\section{Kesimpulan}

Perumahan pemukiman Malimping Utara Kecamatan Malimping Kabupaten Lebak memiliki perbedaan dengan daerah lain sehingga penataan kota di malimping akan berjalan dengan baik untuk tempat tinggal masyarakatnya. Pola konsumsi serta penataan kota malimping dan lingkungannya, kedua faktor tersebut kalau tidak menjalankan dengan baik maka akan terjadi terbatasnya kualitas perumahan pemukiman yang ada.Interaksi sektor publik yang mempunyai kerjasama dalam mempercepat proses pertumbuhan perumahan di malimping utara kecamatan malimping kabupaten Lebak dimana memiliki karekteristik khusus berbeda dari daerah lainnya.

Tata ruang Malimping Utara Kecamatan Malimping Kabupaten Lebak melalui tinjauan falsafah, persepsi, serta pendekatan tata ruang yang semestinya melalui dualisme antara pihak-pihak yang berkepentingan dan terkait, yaitu pihak penyedia dengan pendorong, provider dengan enabler. Menurut Bianpoe (1992), pembangunan perumahan penduduk bertumpu pada kepentingan masyarakat Malimping. Adapun kepentingan tersebut meliputi: aspirasi kebutuhan, kemampuan serta upaya masyarakat. 
Efektivitas manajemen properti akan menjadi salah satu faktor yang mendukung kesuksesan pembangunan perumahan, selain faktor pembangunan yang berwawasan lingkungan dan pembangunan perumahan untuk masa depan yang berpijak pada kemandirian penduduk Malimping yang berdasarkan azas manfaat,kebersamaan dan kekeluargaan, adil-merata, kepercayaan diri, kelestarian lingkungan, keterjangkauan, penataam perumahan yang berdimensi politik, ekonomi, sosial, budaya, hukum, falsafah, dan perundang-undangan.

Perkembangan produk dengan rencana serta kenyamanan berdasarkan prinsip komprehensif yaitu:

1. Rencana umum perlu seimbang dari produk serta menarik sesuai kebutuhan saat ini serta masa depan.

2. Prospek penduduk ekonomi suatu daerah sebanding dengan prospek penduduk dalam hal perumahan pemukiman.

3. Sumber keuangan saat ini pada prospeknya juga sebanding dengan apa yang sudah direncanakan.

Substansi dari rencana komprehensif yaitu: perencanaan lahan, perencanaan sirkulasi, perencana sarana prasarana perumahan, serta sarana penting untuk mencapai tujuan fisik, ekonomi dan sosial.
Kebijakan investasi pemerintah dalam perumahan pemukiman dalam rencana penggunaan lahan bersama developer swasta mempunyai pengaruh kuat pada laju pertumbuhan pengembangan perumahan pemukiman karena pola karakter lingkungan dan fisik di malimping utara kecamatan malimping kabupaten Lebak, mendorong peningkatan dan pelestarian saat ini dan amsa yang akan datang. Serta mengupakayan perluasan perkembangan daerah malimping Kabupaten Lebak secara rasional, efisien, dan teratur di kawasan yang masih belum berkembang lainnya.

Secara optimal serta terkendali dicerminkan dalam asas manfaat dalam menentukan tingkatan serta fungsi dari kegiatan pelayanan dan sistem sarana prasarana di wilayah Malimping Kabupaten Lebak. Untuk keserasian dalam prinsip keseimbangan juga mesti mencakup di dalamnya perihal pemanfaatan ruang yang telah ditata dan diatur bagi penyebaran penduduk di kabupaten Lebak lintasan kawasan sektor serta tercapainya keserasian dalam sumber daya manusia, alam serta lingkungan hidup. Penting juga tercipta hubungan yang serasi antara manusia.

Kebutuhan akan perumahan bagi penduduk serta keterbatasan lahan tanah untuk membangun yang dibarengi dengan perkembangan penduduk yang memiliki sifat dinamis mesti diapahami dan juga dicermati perubahannya dari waktu ke waktu. Seringkali perubahan terjadi karena adanya keseimbangan 
sebagai langkah bijaksana. Karena itu perlu adanya kebijakan serta perencanaan yang bersifat menyeluruh dari pemerintah, masyarakat serta akademisi.

\section{Saran}

Perencanaan suatu wilayah perlu pengaturan pola konsumsi masyarakat dalam perumahan pemukiman di malimping utara kecamatan malimping Kabupaten Lebak harus mempunyai perencanaan pembangunan peruhaman pemukiman secara matang yang harus dipertimbangkan semuanya teramsuk daerah resapan air, sistem pengairan, tata peruntukan wilayah perumahan pemukiman dimanapun.

Maysarkat pola konsumsi harus diarahkan pada konsumsi investasi perumahan pemukiman dapat meningkat karena akan kebutuhan untuk tempat berteduh.

Diharapkan developer perumaham pemukiman secara bersama-sama dengan perintah provinsi banten dan pemerintah kabupaten Lebak untuk membangun perumahaan lebih giat lagi. 


\section{DAFTAR PUSTAKA}

A Chang Richards \& Patangaroa, R \& S.J Raftery \& Wilkinon \& D.H Aquino (2018). Challenges to building housing resilience: the case of Fiji postcyclone Winston. Procedia engineering, 212, 475-480.

Shuttleorth. R. \& Meekosha. H. (2009). What's so 'critical'about critical disability studies?.Australian Journal of Human Rights. 15(1), 47-75.

Tang. Y. \& Chia W.M. Li. M. (2017). Public and private housing markets dynamics in Singapore: The role of fundamentals. Journal of Housing Economics, 36, 4461.

Yap, K. S. (2016). The enabling strategy and its discontent: Low income housing policies and practices in Asia.Habitat International.54, 166-172.

Vizek. M \& Sonje. A.A, \& Casni. A.C. (2014). The effect of housing and stockmarket wealth on consumption in emerging and developed countries. Economic systems.38(3), 433-450. 